Research Article

\title{
Blood and Milk Beta-hydroxybutyric Acid Concentrations in Different Dairy Cattle Breeds and Association of Subclinical Ketosis with Postpartum Health Disorders, Culling Rate, Body Condition Score, Parity and Milk Production in Holstein
}

\author{
Kemal AKSOY ${ }^{1, a(*)}$ Abdülkerim DENIZZ ${ }^{2, b}$ Serdar DEMİR ${ }^{3, c}$ Ali Cesur ONMAZ ${ }^{4, d}$
}

\author{
${ }^{1}$ University of Muğla Sttkı Koçman, Faculty of Veterinary Medicine Milas, Department of Internal Medicine, TR-48200 Milas, \\ Muğla - TÜRKIYE \\ ${ }^{2}$ Free Researcher, Nispetiye Mah. Bakır Sok. No. 1, TR-34340 Beşiktaş, İstanbul - TÜRKİYE \\ ${ }^{3}$ University of Muğla Sitkı Koçman, Faculty of Science, Department of Statistics, TR-48000 Kötekli, Muğla - TÜRKIYE \\ ${ }^{4}$ University of Erciyes, Faculty of Veterinary Medicine, Department of Internal Medicine, TR-38280 Talas, Kayseri, TÜRKIYYE \\ ORCIDs: a ORCID: 0000-0003-0149-6688; ${ }^{\mathrm{b}}$ ORCID: 0000-0002-5242-5671; ' ORCID: 0000-0002-7504-6383; ${ }^{\mathrm{d}}$ ORCID: 0000-0002-9942-5134
}

Article ID: KVFD-2021-26804 Received: 16.11.2021 Accepted: 26.02.2022 Published Online: 02.03.2022

\begin{abstract}
The aim of the study was to analyse beta-hydroxybutyric acid concentration in the blood (BBAC) and milk (MBAC) at postpartum week 2 (PPW2) and week 4 (PPW4) in Holstein $(n=216,8$ farms), Montbeliard $(n=23)$, Simmental $(n=38)$ and Holstein/Montbeliard Crossbreed ( $n=23$, BBAC only). Furthermore, the prevalence of subclinical ketosis (SCK) and its association with postpartum health disorders (PPHD), body condition score (BCS) and average daily milk yield in 90 days in milk (90DIM) were evaluated in Holstein. Holstein-Crossbreed and Montbeliard had significantly lower postpartum BBAC than others. Primiparous Montbeliard and Holstein had significantly higher MBAC at PPW2 than PPW4. Cows having BCS2 and 4 at calving had higher MBAC at PPW2 and 4 that was associated significantly with metritis and multiple diseases. Holstein with BCS4 at calving had higher BBAC at PPW2 and 4. SCK prevalence in the blood (BBAC $\geq 1.2 \mathrm{mmol} / \mathrm{L}, \mathrm{BSCK}$ ) and milk (MBAC=100 $\mu \mathrm{mol} / \mathrm{L}, \mathrm{MSCK} 1)$, (MBAC $\geq 200 \mu \mathrm{mol} / \mathrm{L}, \mathrm{MSCK} 2)$ and (MBAC $\geq 100 \mu \mathrm{mol} / \mathrm{L}, \mathrm{MSCK} 1 / 2)$ was 8.3, 11.8, 5.8 and $17.3 \%$ at PPW2 and 4.7, 4.9, 6.9 and $11.9 \%$ at PPW4 in Holstein respectively. Holstein with SCK was more likely to develop PPHD in 90DIM. MSCK1 and MSCK1/2 did not associate milk production loss in Holstein. Holstein with BSCK and MSCK2 at PPW2 had a $6.7 \mathrm{~kg}$ loss of average daily milk yield in 90DIM. Culling rate was 3.7\% in Holstein and MSCK2 positive Holstein at PPW2 was significantly more likely to be culled $(25 \%$, Odds:11.2, $\mathrm{P}<0.05)$ in 90DIM. In conclusion, cows having BCS2 and 4 at calving had higher MBAC and BBAC at PPW2 and 4. Holstein-Crossbreed and Montbeliard had much lower postpartum BBAC than Holstein and Simmental. BSCK and MSCK2 caused significantly risk factor for PPHD, culling rate and milk production in Holstein.
\end{abstract}

Keywords: Beta-hydroxybutyric acid, Holstein, Metabolic diseases, Montbeliard, Simmental, Subclinical ketosis

\section{Farklı Süt Sığırı Irklarında Kan ve Süt Beta-hidroksibüitirik Asit Düzeyleri ve Holstein'larda Subklinik Ketozisin Postpartum Hastalıklar, Sürüden Ayırma, Vücut Kondisyon Skoru, Parite ve Süit Verimi İle İlişkisi}

\begin{abstract}
Öz: Bu çalı̧manın amacı beta-hidroksibütirik asit konsantrasyonlarını kanda (KBAK) ve sütte (SBAK) Holstein ( $\mathrm{n}=216,8$ çiftlik), Montbeliard ( $\mathrm{n}=23)$, Simmental $(\mathrm{n}=38)$ ve Holstein- Montbeliard melezlerinde (HMM, n=23, yalnız KBAK) postpartum 2. ve 4. haftada (PPH2 ve PPH4) ölçmektir. Ayrıca, subklinik ketozis (SK) prevalansı ile irtibatlı doğum sonrası ilk 90 gündeki postpartum metabolik hastalıklar (PPMH), vücut kondisyon skoru (VKS) ve günlük ortalama süt verimi Holstein ırkında değerlendirilmiştir. HMM ve Montbeliard’larda diğerlerine göre anlamlı olarak daha düşük KBAK oranı tespit edilmiştir. Primiparous Montbeliard ve Holstein rrklarında SBAK PPH2'de PPH4’e göre önemli oranda yüksek çıkmıştır. VKS'si doğumda 2 veya 4 olan hayvanlar PPH2 ve 4'de anlamlı derecede daha yüksek SBAK’a sahip oldukları görülmüştür ve bu hayvanlarda metritis ve çoklu hastalık görülme oranı yüksek çıkmıştır. Doğumda VKS4'e sahip Holstein'lar PPH2 ve 4'te daha yüksek KBAK’a sahiplerdi. Holstein'larda SK prevalansı PPH2'de kanda (KBAK $\geq 1.2 \mathrm{mmol} / \mathrm{L}$, KSK) ve sütte [SBAK=100 $\mu \mathrm{mol} / \mathrm{L}$ (SSK1), SBAK $\geq 200 \mu \mathrm{mol} / \mathrm{L}$ (SSK2), SBAK $\geq 100 \mu \mathrm{mol} / \mathrm{L}$ (SSK1/2)] sirasılyla 8.3, $11.8,5.8$ ve $17.3 \%$ ve PPH4'de sırasıyla 4.7, 4.9, 6.9 ve 11.9\% olarak tespit edilmiștir. SK pozitif olan Holstein ırkında, doğum sonrası ilk 90 günde PPMH gelişme oranı anlamlı derecede risk oluşturmuştur. SSK1'in ve SSK1/2'nin süt verimi ile ilişkisi tespit edilmemiștir. PPH2'de hem KSK hem de SSK2'ye sahip Holstein'larda, ilk 90 günde günlük ortalama $6.7 \mathrm{~kg}$ süt verimi kaybı görülmüștür. Doğum sonrası ilk 90 günde sürüden ayırma oranı Holstein ırkında \%3.7 oranında görülmüș ve bunlardan PPH2'de SSK2 pozitif olanlar anlamlı derecede yüksek riskli çıkmışlardır (Odds 11.2, \%25, P<0.05). Sonuç olarak, doğumda VKS2 ve 4'e sahip hayvanlarda PPH2 ve 4’te SBAK ve KBAK düzeylerinin daha yüksek olduğu gözlenmiștir. Montbeliard ve HMM'lerin postpartum KBAK'ları Holstein ve Simmental'lerden daha düşük çıkmıştır. KSK ve SSK2, Holstein'larda PPMH, sürüden ayırma ve süt verimi için önemli bir risk oluşturmuştur.

Anahtar sözcükler: Beta-hidoksibütirik asit, Holstein, Metabolik hastalk, Montbeliard, Simmental, Subklinik ketozis
\end{abstract}

How to cite this article?

Aksoy K, Deniz A, Demir S, Onmaz AC: Blood and milk beta-hydroxybutyric acid concentrations in different dairy cattle breeds and association of subclinical ketosis with postpartum health disorders, culling rate, body condition score, parity and milk production in Holstein. Kafkas Univ Vet Fak Derg, 28 (2): 235-246, 2022. DOI: $10.9775 / \mathrm{kvfd} .2021 .26804$

${ }^{(*)}$ Corresponding Author

Tel: +90 5333676057

E-mail: kemalaksoyviyana@gmail.com (K. Aksoy)

(i) (8) This article is licensed under a Creative Commons Attribution-NonCommercial 4.0 International License (CC BY-NC 4.0) 


\section{INTRODUCTION}

Dairy cows must orchestrate the metabolic challenges during the transition from dry-period to early lactation to support milk production with an adequate glucose supply. These critical production stages can result in several postpartum metabolic disorders if dairy cows do not overcome the negative energy balance (NEB) due to reduced dry matter intake and other complications ${ }^{[1-3]}$. The NEB is the main reason during the transition period and can negatively affect milk production due to subclinical ketosis (SCK) ${ }^{[4]}$, metabolic and reproduction parameters ${ }^{[3,5,6]}$ and farm profitability through decreased milk production and increased risk of metabolic diseases ${ }^{[3,7-9]}$. Increased demand for milk consumption resulted in increased annual milk production per cow from roughly $2.000 \mathrm{~kg}$ to $10.300 \mathrm{~kg}$ worldwide ${ }^{[1]}$. The dairy cattle population transformed from indigenous low milk yielding breed to high milk yielding dairy breeds from 1991 to 2019 which resulted in increased milk production per cow from 1.4 ton to 3.1 ton and annually from 8.6 Mio ton to 20.7 Mio ton respectively in Turkey ${ }^{[10]}$. However, this brought problems of metabolic and reproductive diseases such as ketosis, displaced abomasum resulting in early culling ${ }^{[10]}$. SCK was associated with increased level of beta-hydroxybutyric acid (BHBA) also called hyperketonemia or hyperketolactia in the absence of clinical ketosis signs and it is a common disease for high milk yielding dairy cows. Beta-hydroxybutyric acid concentration (BAC) in the blood (BBAC) or milk (MBAC) is one of the most tested ketone bodies among others as such acetone and acetoacetic acid in recent years ${ }^{[3,9,11]}$. Testing of BBAC ${ }^{[9,11-13]}$ and MBAC ${ }^{[14-16]}$ indicate the NEB, that can result in clinical ketosis and SCK in early lactation. Thus, hyperketonemia became an economically relevant postpartum metabolic problem in terms of its impact on farm profitability, especially in Holstein dairy farming ${ }^{[3,7,8,17]}$, however, there are not enough papers published about Montbeliard, Simmental and Holstein-Crossbreed. Various studies in Holstein revealed a prevalence of $21.8 \%{ }^{[11]}$ and $24 \%{ }^{[13]}$ worldwide if tested in the blood, in which a cutoff level for $\mathrm{BBAC} \geq 1.2 \mathrm{mmol} / \mathrm{L}$ was taken. Studies from Turkey reported that the prevalence was $11.2 \%^{[11]}$ and $19.4 \%{ }^{[12]}$ with the same BAC threshold. Recent studies showed that checking of MBAC found large acceptance by using Fourier-Transform Infrared Spectrometry ${ }^{[16]}$ or milk ketone strips ${ }^{[9,14]}$. A prevalence of $39 \%$ in Holstein was reported by using milk ketone strips in European countries. This rate was $22.6 \%$ by using Fourier-Transform Infrared in Canada ${ }^{[14]}$. The cut-off value of MBAC for the definition of SCK varied among the studies. Few papers used MBAC to define SCK prevalence. Ranges of MBAC to classify cows with suspect of hyperketolactia ( 0.15 to $0.19 \mathrm{mmol} / \mathrm{L})$ or positive hyperketolactia $(\geq 0.20$ $\mathrm{mmol} / \mathrm{L}$ ) were reported by Benedet et al. ${ }^{\left[{ }^{[9]}\right.}$ and others ${ }^{[14,18]}$.
The relationship between BBAC and MBAC and milk production was studied in Holstein cows ${ }^{[15,19]}$. Most of the studies about the prevalance of SCK were cunducted via a blood test only. A few studies reported the correlation between BBAC and MBAC and the prevalence of SCK defined by different cut-off values in milk, as well as its association with PPHD, culling rate, body condition score (BCS) and parity. The majority of the studies about the prevalence of SCK and its association with PPHD were conducted in Holstein dairy farms. Montbeliard and Simmental were classified in the same family ${ }^{[20,21]}$ and there are no comparative analysis about BBAC and MBAC in different parities compared to Holstein. Although there was a correlation between hyperketonemia and hyperketolactia ${ }^{[22]}$, there is also a lack of research conducted for the comparison of BAC in the blood and milk in various breeds at most critical time points postpartum week 2 and 4 (PPW2 and PPW4) worldwide. The aim of the present study was to compare the relationship of BBAC and MBAC with parity and BCS at two different postpartum time points in Holstein, Simmental, Montbeliard and Holstein-Crossbreed dairies. Furthermore, the present study aimed to analyse the prevalence of SCK defined with hyperketonemia and hyperketolactia at two most important time points such as PPW2 and PPW4 and its associations with PPHD, culling, BCS, parity and milk production in Holstein.

\section{Material and Methods}

\section{Ethical Statement}

The study was approved by the Animal Experiments Local Ethics Committee of University of Erciyes (EÜHADYEK) with the ethical approval number of 15.05.2019/05/19-113.

\section{Animals and Grouping}

This is a randomized field study. The study was conducted in 4 provinces (İzmir, Aydın, Muğla and Denizli) of Turkey. The present study was conducted between September 2019 and March 2020. Three hundred lactating cows in 11 integrated dairy cattle farms consisting of Holstein $(\mathrm{n}=216$, farm 1 to 8$)$, Simmental $(\mathrm{n}=38$, farm 9 and 11$)$, Montbeliard ( $\mathrm{n}=23$, farm 1) and Holstein-Crossbreed (HC) (HolsteinxMontbeliard, $n=23$, farm 10) were enrolled for the study. Parity groups were created as primiparous (PRP) and multiparous (MUL) due to association of SCK with the parity ${ }^{[1,22]}$. Furthermore, groups were created for the definition of SCK in the blood (BSCK) and milk (MSCK1, MSCK2 and MSCK1/2) based on appropriate cut-points of BBAC and MBAC. Combined prevalence groups such as BSCK/MSCK positive and BSCK or MSCK positive both at postpartum week 2 and 4 were created to observe their effects on the average daily milk yield (ADMY) in Holstein. Farms $(n=8)$ that had an automatic milking system, milk yield recording database, and complete milk 
yield recording for study animals ( $n=206$ Holstein) were enrolled in the milk production analysis.

\section{Animal Feeding}

All farms had a professional self-ration program and, cows were fed with a ration according to the production cycle, energy, mineral and other nutrients requirements (dry period, close-up, early lactation). Water was served ad libitum. Farm feeding strategy and ration have not been changed or specifically prepared for this study and throughout the research period. Cows in the study farms fed with a ration consisting of maize silage, hay, alfalfa, concentrated milk feed, maize flake, cottonseed, limestone, soy sauce, vitamin and mineral premix that had the metabolic energy of 41.77 to $54.30 \mathrm{Mcal} /$ day for a cow in early lactation.

Beta-hydroxybutyric Acid Analysis and Definition of SCK in the Blood and Milk

BBAC was analysed in the individual whole blood samples collected from the coccygeal vein by a practical cowside analyser ${ }^{[23]}$ (Medtrust Wellionvet Belua, Med Trust Handelsges.m.b.H., Austria) at PPW2 and PPW4. Semiquantitative MBAC was analysed at the same times like blood test in $50 \mathrm{~mL}$ of freshly taken individual milk samples (within 5 min after collection) with milk-test-strips ${ }^{[24]}$ (Ketotest, Elanco). SCK without clinical signs of ketosis (e.g. constipation, anorexia, rumen dysfunction, reduced rumination) was defined by a cut-off point of $\mathrm{BBAC} \geq 1.2$ $\mathrm{mmol} / \mathrm{L}(\mathrm{BSCK})$ in the blood ${ }^{[10,13]}$ and $\mathrm{MBAC}=100 \mu \mathrm{mol} / \mathrm{L}$ (MSCK1), MBAC $\geq 200 \mu \mathrm{mol} / \mathrm{L}$ (MSCK2) and MBAC $\geq 100$ $\mu \mathrm{mol} / \mathrm{L}(\mathrm{MSCK} 1 / 2)$ in the milk as recommended by the test kits manufacturer and others ${ }^{[9,14,15,18]}$.

\section{Body Condition Scores and Postpartum Health Checks}

BCS controls were performed according to the recommendations by Edmonson et al. ${ }^{[25]}$ based on a scale from 1 to 5 at calving (postpartum day 0), postpartum day 30 (PP30) and day 60 (PP60). Groups for $\mathrm{BCS}<2.5$ (BCS1), $\mathrm{BCS} \geq 2.5-<3.5$ (BCS2), BCS $\geq 3.5$ to $<4.0$ (BCS3) and BCS $\geq 4.0$ (BCS4) were set up. The difference of BCS relative to calving was the body condition loss or gain ${ }^{[26]}$. Cows were monitored and evaluated daily from the clinical health point of view for PPHD, any single or multiple diseases or culling were registered immediately in 90 days in milk (90DIM). They were specifically checked for retained placenta, displaced abomasum, metritis, mastitis, cystic ovarian, lameness, clinical ketosis, milk fever or combined multiple diseases (more than 1 disease) in 90DIM because they were most prevalent PPHD associated with SCK ${ }^{[3,5-8,22]}$.

\section{Milk Yield Recording}

The daily milk yield of Holstein $(n=206)$ was recorded automatically in the study farms $(n=8)$ where various automated milking system was set and continuously recorded in a data base. Milk yield was taken directly from computerized farm database.

\section{Statistical Analysis}

Statistical analyses were performed using the SPSS (version 22) software and the results were evaluated for $\alpha=0.05$. The normality of the data was evaluated by Kolmogorov-Smirnov and Shapiro-Wilks tests. MannWhitney-U, Wilcoxon Signed Ranks and Kruskal-Wallis, Friedman were used for statistical analysis because of the non-normality of the data and small sample sizes. Arithmetic mean (m), standard error (se) or minimum and maximum values were presented as descriptive statistics. Prevalence of BSCK and MSCK1, MSCK2 and MSCK1/2 was presented as numeric, positive, negative and $\%$ in Holstein. In order to evaluate the disease incidences and dependency of BHBA between PPW2 and PPW4, Fisher's exact test was used. Incidence of the PPHD was presented as a percentage. The odds ratio was determined for each of the diseases (for those with sufficient data for computation) in SCK groups. Pearson correlation coefficients were calculated between BBAC/BSCK and MBAC/MSCK at PPW2 and PPW4 and between PPW2 and PPW4 for BBAC/BSCK and MBAC/MSCK. BBAC and MBAC were analysed by Wilcoxon Signed Ranks test to compare PPW2 with PPW4. However, Kruskal-Wallis test was used for the analysis between breed groups. BBAC and MBAC between each breed group were compared with Mann-Whitney-U Test. The ADMY was analysed using Mann-Whitney-U test between SCK positive and negative cows, including subgroups. Repeated measure ANOVA and Friedman tests were initiated for the analysis of milk yield between calving and postpartum 12 weeks.

\section{RESUlTS}

\section{BBAC, MBAC, BCS and Parity in Different Dairies}

The averages of BCS, BBAC and MBAC in the study cows were presented in Table 1. All cows lost BCS at PP30 and PP60 compared to calving BCS, except for PRP Simmental. BCS1 was not observed at calving. BCS2, BCS3 and BCS4 were detected in Holstein by $47 \%, 41 \%$, and $8.6 \%$ at calving respectively. The average parity of Holstein, Montbeliard, Simmental and HC was $2.93 \pm 0.11(\mathrm{n}=37$ PRP, $n=179$ MUL), 3.09 \pm 0.31 ( $n=5$ PRP, $\mathrm{n}=18 \mathrm{MUL}$ ), $2.26 \pm 1.03$ (n=9 PRP, n=29 MUL), $2.04 \pm 1.15$ $(\mathrm{n}=11 \mathrm{PRP}, \mathrm{n}=12 \mathrm{MUL})$ respectively. The average parity of Simmental and $\mathrm{HC}$ was significantly lower $(\mathrm{P}<0.01)$ than Montbeliard and Holstein. Fig. 1 and Fig. 2 present BBAC and MBAC for different BCSs at calving. Calving-BCS determined significantly BBAC and MBAC at PPW2 and PPW4. Holstein having significantly high BBAC at PPW2 had BCS4 at PP30 and PP60. Significantly high BBAC at PPW2 was observed in Simmental having BCS4 at PP30 $(\mathrm{P}<0.01)$. Correlation coefficients (data not shown in 


\begin{tabular}{|c|c|c|c|c|c|c|c|}
\hline Cows & Groups & All Breeds & Holstein & Montbeliard & Simmental & HC & $\mathbf{P}(1)$ \\
\hline \multirow{10}{*}{$\begin{array}{c}\text { All } \\
\text { parities }\end{array}$} & BCS-calving & $3.42 \pm 0.03^{1}$ & $3.35 \pm 0.03^{\mathrm{a}, 1}$ & $3.52 \pm 0.04^{\mathrm{b}, 1}$ & $3.59 \pm 0.10^{\mathrm{b}, 1}$ & $3.61 \pm 0.08^{\mathrm{b}, 1}$ & 0.00 \\
\hline & BCS-PP30 & $2.96 \pm 0.02^{2}$ & $2.94 \pm 0.03^{\mathrm{a}, 2}$ & $2.80 \pm 0.04^{\mathrm{a}, 2}$ & $3.24 \pm 0.08^{\mathrm{b}, 2}$ & $2.83 \pm 0.09^{\mathrm{a}, 2}$ & 0.00 \\
\hline & BCS-PP60 & $2.96 \pm 0.03^{2}$ & $2.88 \pm 0.03^{\mathrm{a}, 3}$ & $2.88 \pm 0.02^{\mathrm{a}, 2}$ & $3.41 \pm 0.09^{\mathrm{b}, 1}$ & $2.87 \pm 0.06^{\mathrm{a}, 2}$ & 0.00 \\
\hline & $\mathrm{P}(2)$ & 0.00 & 0.00 & 0.00 & 0.01 & 0.02 & - \\
\hline & PPW2-BBAC & $0.48 \pm 0.04$ & $0.54 \pm 0.05^{\mathrm{a}}$ & $0.32 \pm 0.07^{b}$ & $0.45 \pm 0.01^{\mathrm{a}}$ & $0.03 \pm 0.04^{c}$ & 0.00 \\
\hline & PPW4-BBAC & $0.42 \pm 0.03$ & $0.46 \pm 0.04^{\mathrm{a}}$ & $0.33 \pm 0.03^{\mathrm{b}}$ & $0.44 \pm 0.04^{\mathrm{a}}$ & $0.02 \pm 0.09^{c}$ & 0.00 \\
\hline & $\mathrm{P}(3)$ & 0.21 & 0.11 & 0.43 & 0.95 & 0.48 & - \\
\hline & PPW2-MBAC & $62.98 \pm 9.01$ & $76.73 \pm 14.84^{\mathrm{a}}$ & $52.17 \pm 9.68^{\mathrm{a}}$ & $50.00 \pm 0.00^{\mathrm{a}}$ & - & 0.45 \\
\hline & PPW4-MBAC & $55.63 \pm 9.72$ & $67.33 \pm 13.41^{\mathrm{a}}$ & $8.70 \pm 4.04^{\mathrm{b}}$ & $50.00 \pm 0.00^{\mathrm{a}}$ & - & 0.00 \\
\hline & $\mathrm{P}(3)$ & 0.00 & 0.03 & 0.00 & 1.00 & - & - \\
\hline \multirow{10}{*}{ PRP } & BCS-calving & $3.51 \pm 0.05^{1}$ & $3.48 \pm 0.06^{\mathrm{a}, 1}$ & $3.60 \pm 0.10^{\mathrm{a}, 1}$ & $3.56 \pm 0.19^{\mathrm{a}, 1}$ & $3.50 \pm 0.12^{\mathrm{a}, 1}$ & 0.76 \\
\hline & BCS-PP30 & $2.98 \pm 0.05^{2}$ & $2.98 \pm 0.05^{\mathrm{a}, 2}$ & $2.87 \pm 0.12^{\mathrm{a}, 2}$ & $3.17 \pm 0.17^{\mathrm{a}, 1}$ & $2.86 \pm 0.14^{\mathrm{a}, 2}$ & 0.44 \\
\hline & BCS-PP60 & $2.97 \pm 0.06^{2}$ & $2.92 \pm 0.07^{\mathrm{a}, 2}$ & $2.90 \pm 0.05^{\mathrm{a}, 2}$ & $3.33 \pm 0.17^{\mathrm{b}, 1}$ & $2.86 \pm 0.10^{\mathrm{a}, 2}$ & 0.03 \\
\hline & $\mathrm{P}(2)$ & 0.00 & 0.00 & 0.01 & 0.08 & 0.00 & - \\
\hline & PPW2-BBAC & $0.57 \pm 0.07$ & $0.75 \pm 0.17^{\mathrm{a}}$ & $0.52 \pm 0.30^{\mathrm{b}}$ & $0.50 \pm 0.06^{\mathrm{b}}$ & $0.03 \pm 0.02^{c}$ & 0.00 \\
\hline & PPW4-BBAC & $0.40 \pm 0.07$ & $0.51 \pm 0.12^{\mathrm{a}}$ & $0.44 \pm 0.10^{\mathrm{a}}$ & $0.42 \pm 0.08^{\mathrm{a}}$ & $0.01 \pm 0.03^{b}$ & 0.00 \\
\hline & $\mathrm{P}(3)$ & 0.04 & 0.08 & 1.00 & 0.20 & 0.16 & - \\
\hline & PPW2-MBAC & $91.67 \pm 28.85$ & $101.85 \pm 39.63^{\mathrm{a}}$ & $70.00 \pm 20.00^{\mathrm{a}}$ & $50.00 \pm 0.00^{\mathrm{a}}$ & - & 0.57 \\
\hline & PPW4-MBAC & $43.33 \pm 16.56$ & $50.00 \pm 23.40^{\mathrm{a}}$ & $10.00 \pm 10.00^{\mathrm{a}}$ & $50.00 \pm 0.00^{\mathrm{a}}$ & - & 0.10 \\
\hline & $\mathrm{P}(3)$ & 0.00 & 0.03 & 0.06 & 1.00 & - & - \\
\hline \multirow{10}{*}{ MUL } & BCS-calving & $3.39 \pm 0.03^{1}$ & $3.32 \pm 0.03^{\mathrm{a}, 1}$ & $3.50 \pm 0.04^{\mathrm{a}, 1}$ & $3.60 \pm 0.12^{\mathrm{b}, 1}$ & $3.71 \pm 0.11^{\mathrm{b}, 1}$ & 0.00 \\
\hline & BCS-PP30 & $2.95 \pm 0.03^{2}$ & $2.93 \pm 0.03^{\mathrm{a}, 2}$ & $2.78 \pm 0.05^{\mathrm{b}, 2}$ & $3.27 \pm 0.10^{c, 2}$ & $2.79 \pm 0.11^{\mathrm{b}, 2}$ & 0.00 \\
\hline & BCS-PP60 & $2.95 \pm 0.03^{2}$ & $2.87 \pm 0.04^{\mathrm{a}, 3}$ & $2.88 \pm 0.02^{\mathrm{a}, 2}$ & $3.45 \pm 0.11^{\mathrm{b}, 2}$ & $2.88 \pm 0.07^{\mathrm{a}, 2}$ & 0.00 \\
\hline & $\mathrm{P}(2)$ & 0.00 & 0.00 & 0.00 & 0.00 & 0.00 & - \\
\hline & PPW2-BBAC & $0.45 \pm 0.04$ & $0.50 \pm 0.04^{\mathrm{a}}$ & $0.27 \pm 0.03^{\mathrm{b}}$ & $0.43 \pm 0.05^{\mathrm{a}}$ & $0.03 \pm 0.03^{c}$ & 0.00 \\
\hline & PPW4-BBAC & $0.42 \pm 0.03$ & $0.45 \pm 0.04^{\mathrm{a}}$ & $0.29 \pm 0.03^{b}$ & $0.45-0.04^{\mathrm{a}}$ & $0.03 \pm 0.05^{c}$ & 0.00 \\
\hline & $\mathrm{P}(3)$ & 0.68 & 0.36 & 0.41 & 0.57 & 1.00 & - \\
\hline & PPW2-MBAC & $55.86 \pm 8.44$ & $58.04 \pm 10.79^{\mathrm{a}}$ & $47.22 \pm 11.05^{\mathrm{a}}$ & $50.00 \pm 0.00^{\mathrm{a}}$ & - & 0.56 \\
\hline & PPW4-MBAC & $58.93 \pm 11.51$ & $71.88 \pm 15.81^{\mathrm{a}}$ & $8.33 \pm 4.52^{\mathrm{b}}$ & $50.00 \pm 0.00^{\mathrm{a}}$ & - & 0.00 \\
\hline & $\mathrm{P}(3)$ & 0.01 & 0.21 & 0.01 & 1.00 & - & - \\
\hline \multicolumn{8}{|c|}{ 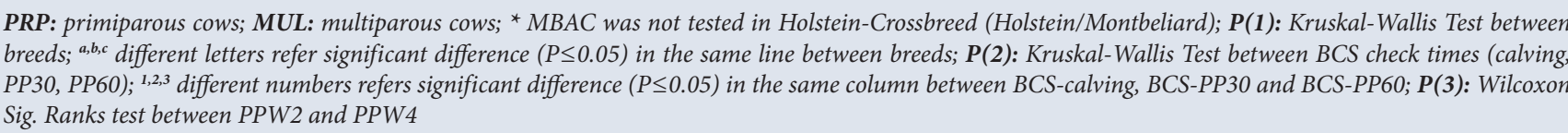 } \\
\hline
\end{tabular}

tables) between BBAC and MBAC were $\mathrm{r}=0.60$ and $\mathrm{r}=0.86$ $(\mathrm{P}<0.05)$ at $\mathrm{PPW} 2$ and it was $\mathrm{r}=0.36$ and $\mathrm{r}=0.14(\mathrm{P}>0.05)$ at PPW4 in Holstein and Montbeliard cows respectively. Correlation coefficients for BBAC and MBAC were $\mathrm{r}=0.45$ and $r=0.75(\mathrm{P}<0.05)$ between PPW2 and PPW4 in Holstein respectively. No significant correlation was found in other breeds.

\section{Prevalence of BSCK and MSCK in Holstein}

SCK prevalence analysis was not performed in the breeds other than Holstein, none of Simmental and $\mathrm{HC}$ cows have exceed the cut-point of BHBA for SCK definition. Out of 23 Montbeliard cows, 1 PRP Montbeliard with BCS4 at calving showed BSCK at PPW2 only, but that cow became negative at PPW4. BSCK was detected in Holstein farms (farms 2, 3, 5, 6, 7 and 8) at PPW2 and 4 respectively. The difference between PPW2 and PPW4 was significant $(\mathrm{P}<0.01)$. Holstein farms 1 and 4 were negative for BSCK. The descriptive data about the prevalence of BSCK and MSCK, their relation with the parity and BCSs were presented in Table 2 for Holstein. PRP Holstein with BSCK at PPW2 and 4, lost significantly $(\mathrm{P}<0.05)$ BCS at PP60. The difference between PPW2 and PPW4 was significant $(\mathrm{P}<0.01)$ in $\mathrm{MSCK} 1 / 2$ and MSCK2 prevalence. MSCK2 prevalence was negative in Holstein farms 1, 3 and 4. No significant difference was found in BCSs of MSCK2 


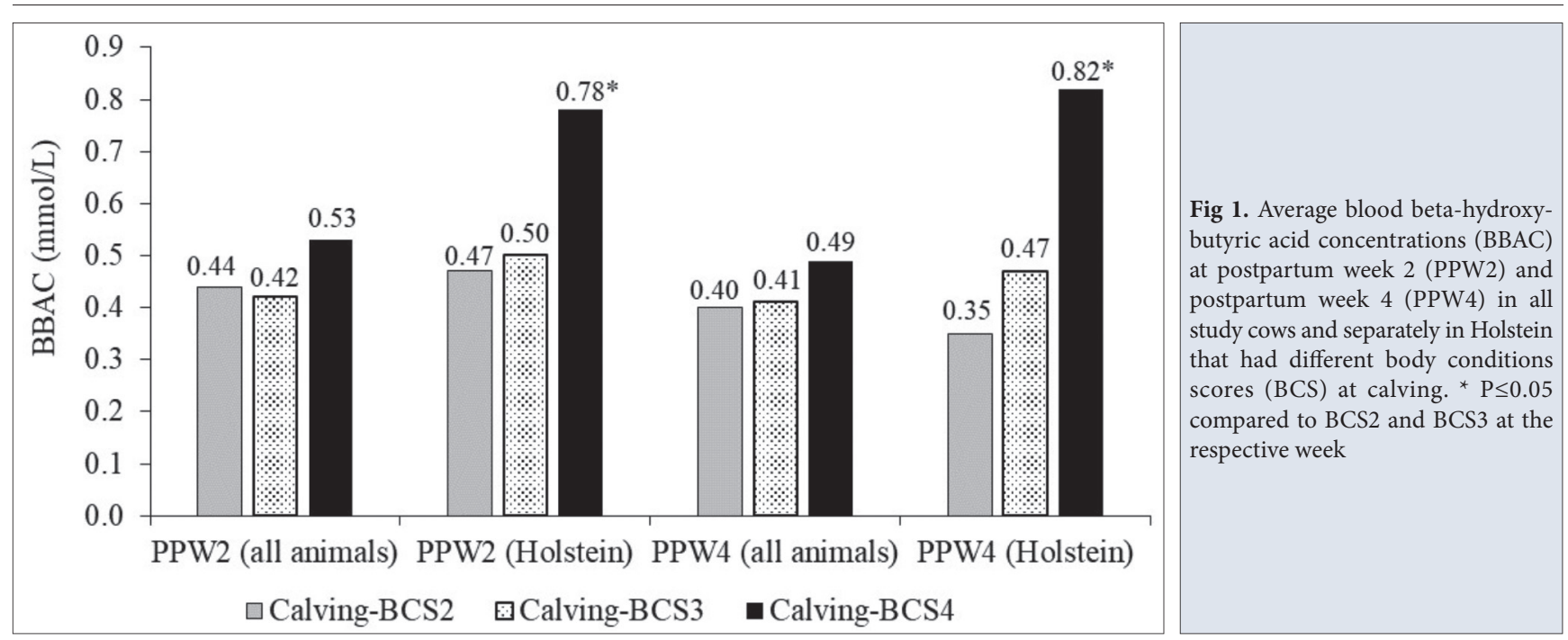

Fig 2. Average milk beta-hydroxybutyric acid concentrations (MBAC) at postpartum week 2 (PPW2) and postpartum week 4 (PPW4) in all study cows and separately in Holstein that had different body conditions scores (BCS) at calving. ${ }^{*} \mathrm{P}<0.01$, significantly different from BCS3

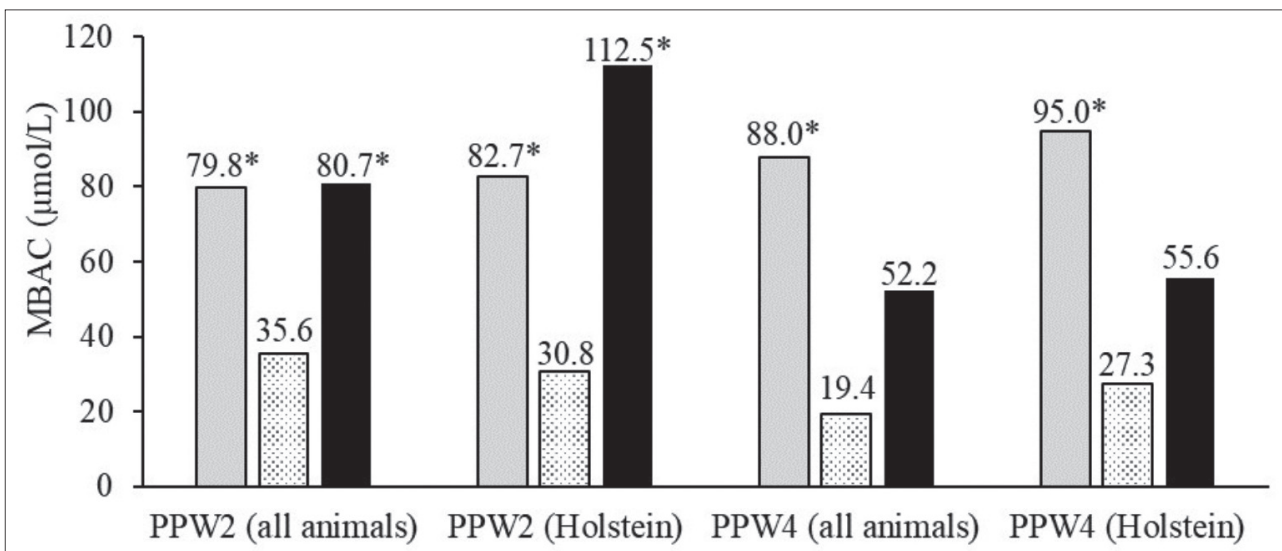

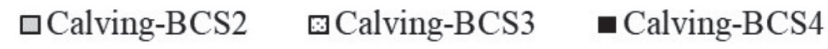

positive MUL Holstein cows between calving, PP30 and PP60. However, all PRP cows with positive MSCK lost BCS between calving, PP30 and PP60. The combined prevalence of BSCK/MSCK1 and BSCK/MSCK2 was 4.0 and $2.0 \%$ at PPW4 in Holstein cows respectively. The prevalence of BSCK/MSCK1/2 was 8.6 and $4.0 \%$ at PPW2 and PPW4 in Holstein respectively. The difference between PPW2 and 4 was significant $(\mathrm{P}<0.01)$. The percentage of BSCK, MSCK1 and MSCK2 positive cases at both PPW2 and PPW4 were 2.3, 5.9 and 3.0\% in Holstein respectively. No correlation for BSCK and MSCK was found between PPW2 and $4(\mathrm{P}>0.05)$. The correlation coefficient was $\mathrm{r}=0.34(\mathrm{P}>0.05)$ for BSCK between PPW2 and PPW4 in Holstein. Correlation coefficients were $r=0.26$ and $r=0.48$ $(\mathrm{P}>0.05)$ for MSCK1 and MSCK2 between PPW2 and PPW4 in Holstein respectively.

\section{Postpartum Health Disorders and Culling in Holstein}

The incidence of PPHD except culling rate and its association with SCK were presented in Holstein in Table 3. MSCK1 did not significantly correlate with PPHD in Holstein and therefore it was not presented. The overall culling rate was 3.7\% among Holstein in 90DIM. Holstein that were positive for MSCK1, MSCK1/2 and MSCK2 at PPW2 created a likelihood of 6.3, 12.5 and 25\% for culling risk respectively. MSCK2 positive cows were significantly more likely (odds ratio: $11.20, \mathrm{P}<0.05$ ) to be culled than even MSCK1/2 (odds ratio: 3.46). MSCK1 did not create a significant risk for culling. The average BCS of culled Holstein was normal (BCS3) at calving, but a significantly BCS loss was observed at PP30 (BCS1). The difference between BCSs of culled Holstein $(2.48 \pm 0.20)$ and nonculled Holstein $(2.95 \pm 0.03)$ was significant at PP30 $(\mathrm{P}=0.026)$. The average parity of culled Holstein was 3.62 (one PRP, 7 MUL). Mastitis $(n=1)$, metritis $(n=1)$ and displaced abomasum $(n=1)$, multiple diseases $(n=1,12 \%)$, lameness $(n=2,25 \%)$ were observed in culled Holstein. Clinical ketosis, displaced abomasum, metritis, mastitis, lameness and multiple diseases were observed moderately and, in some cases, significantly higher in Holstein that were positive for BSCK, MSCK1/2 and MSCK2 at PPW2 or 4 (Table 3). Displaced abomasum and cystic ovarian incidence did not correlate significantly with SCK in Holstein. BSCK and MSCK2 positive Holstein at PPW2 


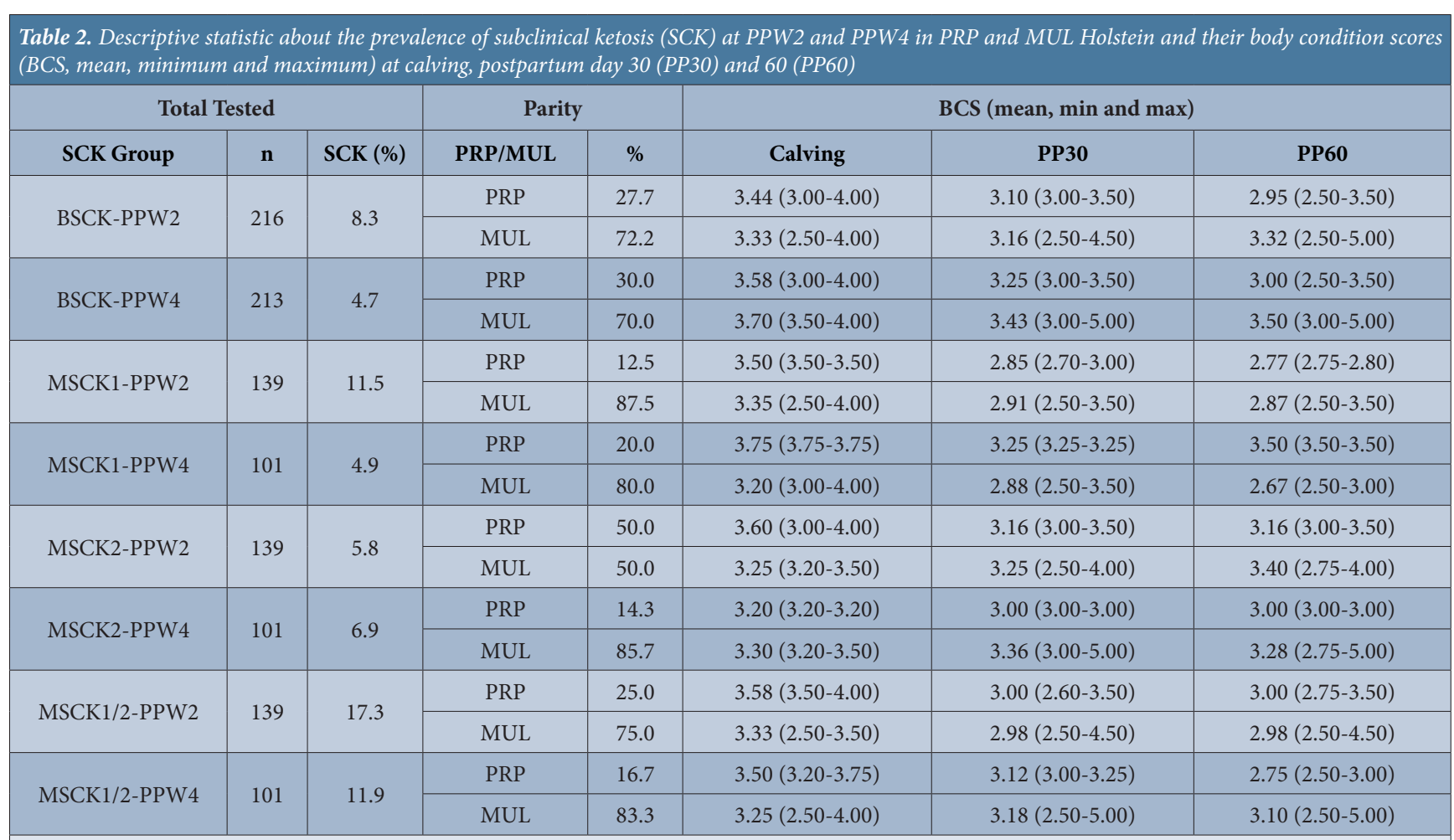

BSCK: blood beta-hydroxybutyric acid concentration $\geq 1.20 \mathrm{mmol} / \mathrm{L} ;$ MSCK1: milk beta-hydroxybutyric acid concentration = 100 $\mu \mathrm{mol} / \mathrm{L} ; \mathrm{MSCK2:}$ milk beta-hydroxybutyric acid concentration $\geq 200 \mu \mathrm{mol} / \mathrm{L} ;$ MSCK1/2: milk beta-hydroxybutyric acid concentration $\geq 100 \mu \mathrm{mol} / \mathrm{L}$; PRP: primiparous; MUL: multiparous; PPW2: postpartum week 2; PPW4: postpartum week 4

\begin{tabular}{|c|c|c|c|c|c|c|c|c|c|c|c|}
\hline \multirow{2}{*}{ SCK group } & \multicolumn{2}{|c|}{ SCK } & \multicolumn{9}{|c|}{ PPHD (\%) } \\
\hline & $\begin{array}{l}\text { Positive/ } \\
\text { Negative }\end{array}$ & $\%$ & CK & RP & DA & Met & Mast & Lam & MF & $\mathrm{CO}$ & MD \\
\hline \multirow{2}{*}{ BSCK-PPW2 } & negative & 91.7 & 0.0 & 2.5 & 1.5 & 6.6 & 17.7 & 11.1 & 1.0 & 3.5 & 6.6 \\
\hline & positive & 8.3 & $44.2^{1}$ & 0.0 & 0.0 & 5.6 & 11.1 & 22.2 & 0.0 & 0.0 & 5.6 \\
\hline \multirow{2}{*}{ BSCK-PPW4 } & negative & 95.3 & 1.5 & 2.5 & 1.0 & 6.4 & 17.2 & 10.3 & 1.0 & 3.4 & 6.4 \\
\hline & positive & 4.7 & $20.0^{2}$ & 0.0 & $10.0^{4}$ & 10 & 20.0 & $30.0^{6}$ & 0.0 & 0.0 & 10.0 \\
\hline \multirow{2}{*}{ MSCK1/2-PPW2 } & negative & 82.7 & 0.9 & 2.6 & 1.7 & 7.0 & 11.3 & 7.8 & 1.7 & 4.3 & 8.7 \\
\hline & positive & 17.3 & 16.7 & 0.0 & 0.0 & 12.5 & 12.5 & 16.7 & 0.0 & 0.0 & 8.3 \\
\hline \multirow{2}{*}{ MSCK1/2-PPW4 } & negative & 88.1 & 2.2 & 0.0 & 1.1 & 7.9 & 10.1 & 5.6 & 1.1 & 5.6 & 7.9 \\
\hline & positive & 11.9 & 8.3 & 0.0 & 8.3 & $25.0^{5}$ & $33.3^{1}$ & 16.7 & 0.0 & 0.0 & $25.0^{7}$ \\
\hline \multirow{2}{*}{ MSCK2-PPW2 } & negative & 94.2 & 1.5 & 2.3 & 1.5 & 7.6 & 10.7 & 9.9 & 1.5 & 3.8 & 0.8 \\
\hline & positive & 5.8 & $37.5^{3}$ & 0.0 & 0.0 & 12.5 & 25.0 & 0.0 & 0.0 & 0 & 12.5 \\
\hline \multirow{2}{*}{ MSCK2-PPW4 } & negative & 93.1 & 2.1 & 0.0 & 2.1 & 9.6 & 11.7 & 7.4 & 1.1 & 5.3 & 9.6 \\
\hline & positive & 6.9 & 14.3 & 0.0 & 0.0 & 14.3 & 28.6 & 0.0 & 0.0 & 0.0 & 14.3 \\
\hline \multicolumn{12}{|c|}{ 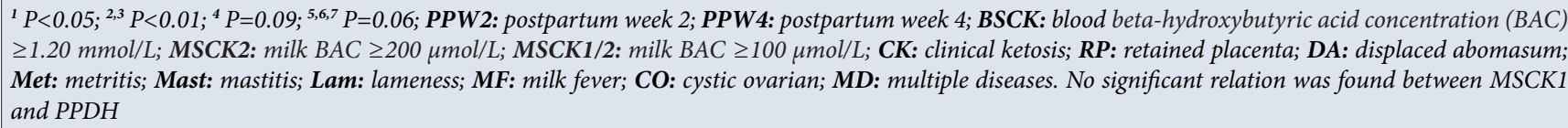 } \\
\hline
\end{tabular}

or 4 were more likely to developing clinical ketosis (odds ratio: 15.4, $\mathrm{P}<0.05)$. Holstein with positive SCK had frequently metritis, however, the incidence was most remarkable in MSCK1/2 positive Holstein at PPW4 $(\mathrm{P}=0.06$, odds ratio: 4.48$)$. Those cows had also a moderate significantly $(\mathrm{P}=0.07)$ lower BCS (2.81) at PP60 than other cows. Holstein with MSCK1/2 at PPW4, were more likely to have mastitis (odds ratio: 5.08, $\mathrm{P}<0.05$ ) (Table 3). Holstein with BSCK at PPW4 had a moderate significantly high incidence of lameness (odd ratio: 4.25, $\mathrm{P}=0.06$ ). 


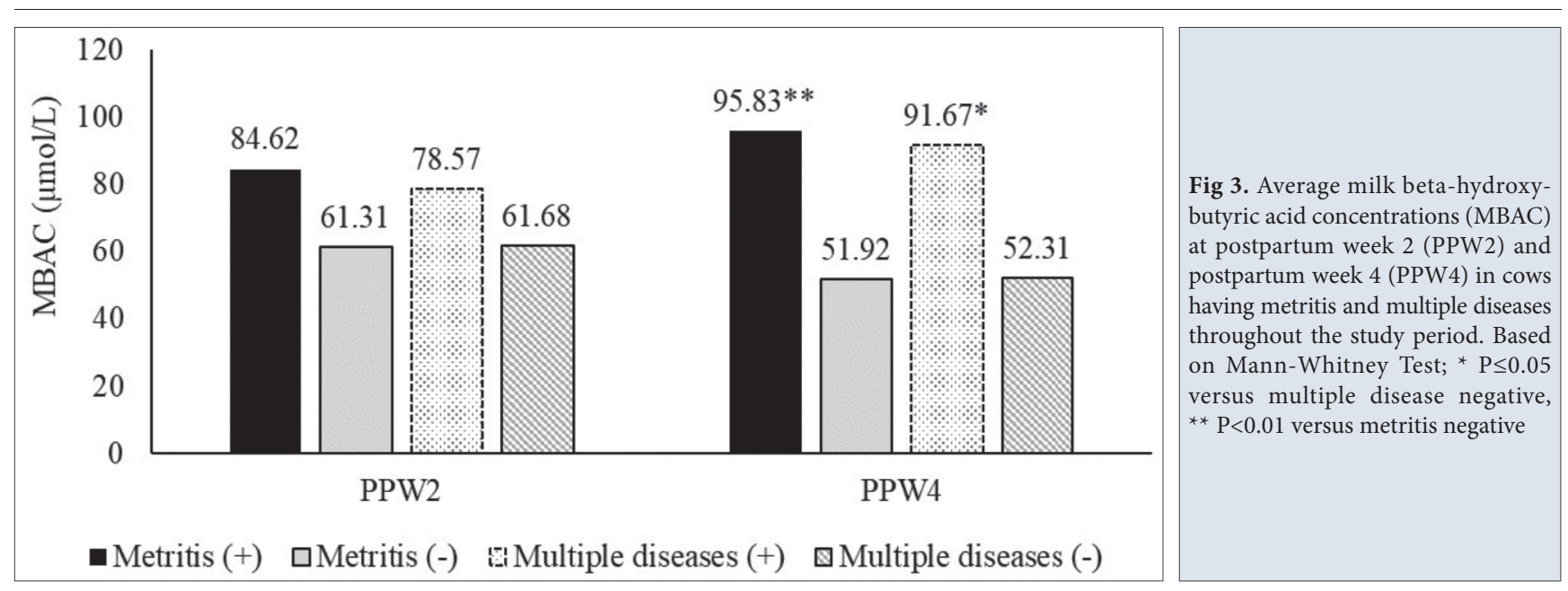

\begin{tabular}{|c|c|c|c|c|c|c|c|c|c|}
\hline \multirow{2}{*}{ SCK Group } & \multicolumn{3}{|c|}{ All Holstein } & \multicolumn{3}{|c|}{ PRP } & \multicolumn{3}{|c|}{ MUL } \\
\hline & Positive & Negative & $\mathbf{P}$ & Positive & Negative & $\mathbf{P}$ & Positive & Negative & $\mathbf{P}$ \\
\hline BSCK at PPW2 & $34.62 \pm 1.55$ & $38.16 \pm 0.65$ & \multirow{2}{*}{0.10} & $33.55 \pm 2.79$ & $40.59 \pm 1.45$ & \multirow{2}{*}{0.05} & $35.16 \pm 1.92$ & $37.70 \pm 0.71$ & \multirow{2}{*}{0.33} \\
\hline $\mathrm{n}$ & 18 & 188 & & 6 & 30 & & 12 & 158 & \\
\hline BSCK at PPW4 & $35.05 \pm 2.19$ & $37.92 \pm 0.63$ & \multirow{2}{*}{0.43} & $33.60 \pm 3.23$ & $39.95 \pm 1.42$ & \multirow{2}{*}{ NA } & $36.24 \pm 1.80$ & $37.56 \pm 0.72$ & \multirow{2}{*}{0.68} \\
\hline $\mathrm{n}$ & 11 & 192 & & 3 & 33 & & 8 & 159 & \\
\hline MSCK2 at PPW2 & $32.46 \pm 2.48$ & $38.02 \pm 0.75$ & \multirow{2}{*}{0.07} & $29.71 \pm 0.66$ & $37.03 \pm 1.21$ & \multirow{2}{*}{ NA } & $34.11 \pm 3.91$ & $38.25 \pm 0.88$ & \multirow{2}{*}{0.31} \\
\hline $\mathrm{n}$ & 8 & 126 & & 3 & 23 & & 5 & 103 & \\
\hline MSCK2 at PPW4 & $33.85 \pm 11.87$ & $36.70 \pm 10.88$ & \multirow{2}{*}{0.47} & 28.39 & $36.63 \pm 1.29$ & \multirow{2}{*}{ NA } & $35.21 \pm 1.66$ & $36.72 \pm 1.07$ & \multirow{2}{*}{ NA } \\
\hline $\mathrm{n}$ & 5 & 97 & & 1 & 21 & & 4 & 76 & \\
\hline
\end{tabular}

MSCK1/2 positive Holstein at PPW4 showed an incidence of 25\% multiple diseases (odds ratio: $4.5, \mathrm{P}=0.06$ ) (Table 3 ). Average MBAC at PPW4 were significantly higher in cows having metritis and multiple diseases (Fig. 3). BBAC at PPW2 was significantly higher in cows with metritis $(\mathrm{P}<0.05)$ in 90DIM (data not shown in tables).

\section{Association of BSCK and MSCK with Average Daily Milk Yield in Holstein}

The comparison of ADMY between SCK positive and negative Holstein was presented in Table 4, 5, 6 and Fig. 4 and 5. The average daily, weekly and monthly milk production of BSCK and MSCK2 negative Holstein had always an upwards trend throughout 12 weeks postpartum in comparison to positive cows (Table 4, 5, 6 and Fig. 4 and 5). The difference between SCK negative and positive cows regarding the ADMY was significant at weeks $10^{\text {th }}, 11^{\text {th }}$ and $12^{\text {th }}$ (Fig. 4 and 5). MSCK2 positive Holstein cows at PPW2 had moderate significantly $(\mathrm{P}=0.07)$ lower ADMY (Table 4). The ADMY was significantly different in Holstein that was in combined prevalence groups of BSCK and MSCK2, and roughly $5.4 \mathrm{~kg}$ and $4 \mathrm{~kg}$ higher ADMY was observed in SCK negative cows than positive cows respectively (Table 5). If Holstein cows were positive both for BSCK and MSCK2 at PPW2, ADMY was $6.7 \mathrm{~kg}$ less than negative cows, which was significant $(\mathrm{P} \leq 0.05)$ (Table 5). MSCK1 and MSCK1/2 in Holstein did not have a significant effect on average daily, weekly and monthly milk yield, even no effect was observed in the combined prevalence groups. Therefore, the data was not presented in the tables. The ADMY of PRP Holstein without BSCK at PPW2 was significantly higher $(\mathrm{P} \leq 0.05)$ than those with BSCK, which meant an average $7 \mathrm{~kg}$ milk yield loos per day (Table 4). Holstein with a negative BSCK and MSCK2 at PPW2 had a much higher ADMY in the second and third months postpartum (Table 6). BSCK negative PRP Holstein at PPW2 had $13.6 \mathrm{~kg}$ more ADMY in the second month of postpartum that was significantly different $(\mathrm{P} \leq 0.05)$ from the positive cows (data not shown in tables).

\section{Discussion}

The present study reported a lower prevalence of BSCK in Holstein than the previous studies by other reports in European countries ${ }^{[11]}$, Turkey ${ }^{[11,12]}$ and worldwide ${ }^{[13]}$, although the same cut-off point of BBAC for BSCK was 
Table 5. Average daily milk production of Holstein $(x \pm s e, k g)$ with positive and negative subclinical ketosis (SCK) in the combined groups at postpartum week 2 or 4 (PPW2 or PPW4) in 90DIM

\begin{tabular}{|c|c|c|c|c|c|}
\hline \multirow{2}{*}{ SCK Group } & \multicolumn{2}{|c|}{ Milk Yield } & \multirow{2}{*}{$\mathbf{P}$} & \multirow{2}{*}{ SCK (\%) } & \multirow{2}{*}{$\begin{array}{l}\text { Not Matching to Group } \\
(\mathbf{n} / \%)\end{array}$} \\
\hline & SCK Positive & SCK Negative & & & \\
\hline BSCK at PPW2 or 4 & $34.25 \pm 1.44$ & $38.24 \pm 0.65$ & \multirow{2}{*}{0.05} & \multirow{2}{*}{11.6} & \multirow{2}{*}{0} \\
\hline n (206) & 24 & 182 & & & \\
\hline MSCK2 at PPW2 or 4 & $32.68 \pm 12.02$ & $38.10 \pm 10.76$ & \multirow{2}{*}{0.05} & \multirow{2}{*}{7.6} & \multirow{2}{*}{0} \\
\hline n (tot:134) & 10 & 124 & & & \\
\hline BSCK/MSCK2 at PPW2 & $31.33 \pm 3.23$ & $37.99 \pm 0.79$ & \multirow{2}{*}{0.05} & \multirow{2}{*}{4.5} & \multirow{2}{*}{$9 / 6.7$} \\
\hline n (tot: 134$)$ & 6 & 119 & & & \\
\hline BSCK/MSCK2 at PPW4 & 36.7 & $36.56 \pm 0.85$ & \multirow{2}{*}{ NA } & \multirow{2}{*}{0.98} & \multirow{2}{*}{$8 / 7.8$} \\
\hline n (tot: 102$)$ & 1 & 93 & & & \\
\hline BSCK or MSCK2 at PPW2 & $34.74 \pm 1.39$ & $38.19 \pm 0.65$ & \multirow{2}{*}{0.09} & \multirow{2}{*}{8.9} & \multirow{2}{*}{0} \\
\hline $\mathrm{n}($ tot: 134$)$ & 12 & 122 & & & \\
\hline BSCK or MSCK2 at PPW4 & $34.88 \pm 1.26$ & $38.07 \pm 0.65$ & \multirow{2}{*}{0.17} & \multirow{2}{*}{8.8} & \multirow{2}{*}{0} \\
\hline n (tot: 102$)$ & 9 & 93 & & & \\
\hline
\end{tabular}

90DIM: 90 days in milk; NA: not applicable; BSCK: blood beta-hydroxybutyric acid concentration $\geq 1.20 \mathrm{mmol} / \mathrm{L}$; MSCK2: milk beta-hydroxybutyric acid concentration $\geq 200 \mu \mathrm{mol} / \mathrm{L}$; These animals cannot be allocated in the respective group because they were positive for one of SCK only

Table 6. Average daily milk production ( $x \pm s e)(\mathrm{kg})$ per month of all Holstein tested for positive (+) or negative (-) of subclinical ketosis (SCK) in the blood (BSCK) and milk (MSCK2) at postpartum week 2 or 4 (PPW2 or 4)

\begin{tabular}{|c|c|c|c|c|c|c|}
\hline \multirow{2}{*}{ SCK Group } & SCK & $\mathbf{n}$ & First Month & Second Month & Third Month & P $^{(1)}$ \\
\hline \multirow{2}{*}{ BSCK at PPW2 } & + & 18 & $32.77 \pm 1.50$ & $34.58 \pm 2.54$ & $35.08 \pm 2.35$ & 0.03 \\
\cline { 2 - 7 } & - & 188 & $34.74 \pm 0.54$ & $39.86 \pm 0.76^{*}$ & $39.89 \pm 0.77^{* *}$ & 0.00 \\
\hline \multirow{2}{*}{ MSCK2 at PPW2 } & + & 8 & $30.25 \pm 2.36$ & $30.74 \pm 5.12$ & $32.92 \pm 4.27$ & 0.16 \\
\cline { 2 - 8 } & - & 126 & $34.42 \pm 0.67$ & $39.91 \pm 0.89^{*}$ & $39.74 \pm 0.85^{* *}$ & 0.00 \\
\hline \multirow{2}{*}{ BSCK at PPW4 } & + & 11 & $33.98 \pm 1.43$ & $34.31 \pm 3.86$ & $36.01 \pm 1.63$ & 0.27 \\
\cline { 2 - 8 } & - & 192 & $34.58 \pm 0.54$ & $39.65 \pm 0.75$ & $39.67 \pm 0.78$ & 0.00 \\
\hline \multirow{2}{*}{ MSCK2 at PPW4 } & + & 5 & $28.22 \pm 2.14$ & $36.51 \pm 2.67$ & $36.81 \pm 2.11$ & 0.07 \\
\cline { 2 - 8 } & - & 97 & $33.61 \pm 0.73$ & $38.38 \pm 1.04$ & $38.11 \pm 1.05$ & 0.00 \\
\hline
\end{tabular}

$P^{(1)}$ : difference between average milk productions of month 1,2, 3; average milk yield of the first month is significantly lower than month $2^{\text {nd }}$ and $3^{\text {rd }}$ where it is applicable ( $P$ value); ${ }^{*} P \leq 0.05 ;{ }^{*} P=0.07$ between $S C K$ positive and negative groups at the respective testing month; BSCK: blood beta-hydroxybutyric acid concentration $\geq 1.20 \mathrm{mmol} / \mathrm{L} ;$ MSCK2: milk beta-hydroxybutyric acid concentration $\geq 200 \mu \mathrm{mol} / \mathrm{L}$

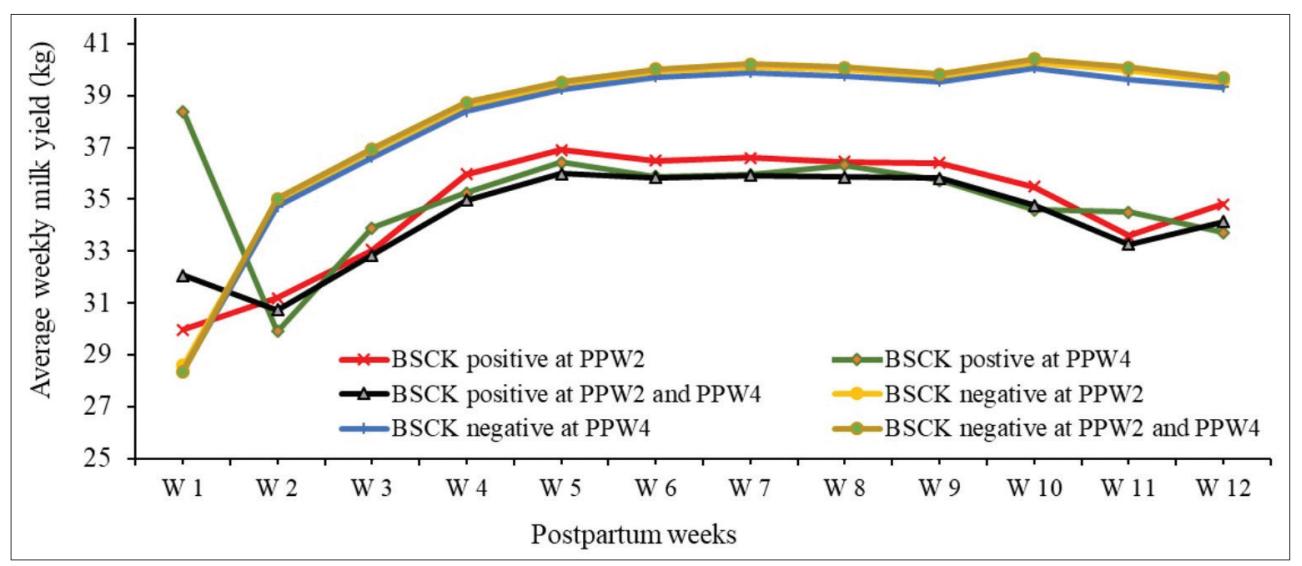

Fig 4. Average daily milk yield per week of Holstein with positive or negative subclinical ketosis (SCK) at postpartum week 2 or 4 (PPW2 or 4) in the blood (BSCK: blood betahydroxybutyric acid concentration $\geq 1.2 \mathrm{mmol} / \mathrm{L}$ ). Remark: line of BSCK negative cows at 'PPW2 and PPW4' overlaps the line of BSCK negative cows at PPW2

used in all these studies. Even, BSCK prevalence was little higher using the lower cut-point of BBAC $(\geq 1.0 \mathrm{mmol} / \mathrm{L})$ in Turkey ${ }^{[27,28]}$. Others defined BSCK by a threshold level of $\mathrm{BBAC} \geq 0.96 \mathrm{mmol} / \mathrm{L}^{[29]}, \geq 1.0 \mathrm{mmol} / \mathrm{L}^{[5,30]}$ and $\geq 1.4 \mathrm{mmol} / \mathrm{L}^{[15,19,24]}$. But, the cut-point of BBAC $\geq 1.20$ $\mathrm{mmol} / \mathrm{L}$ for BSCK definition was found the most acceptance 


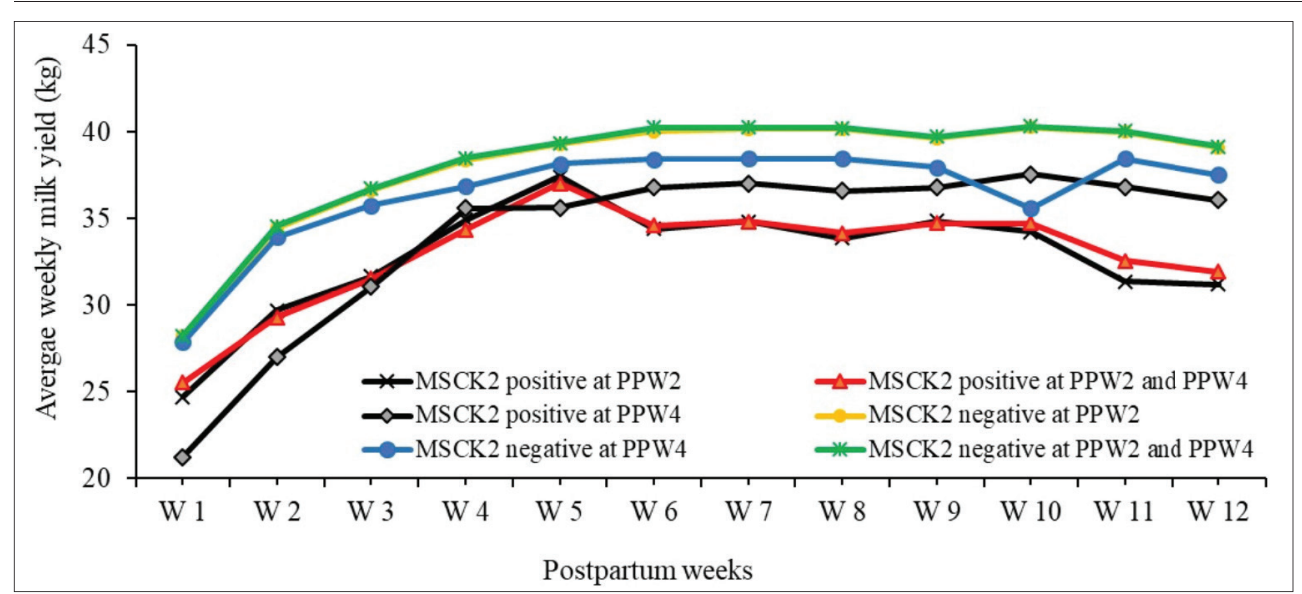

Fig 5. Average daily milk yield per week of Holstein with positive or negative subclinical ketosis (SCK) at postpartum week 2 or 4 (PPW2 or 4) in the milk (MSCK2: milk betahydroxybutyric acid concentration $\geq 200 \mu \mathrm{mol} / \mathrm{L}$ ). Remarks: The line of MSCK2 negative cows at 'PPW2 and PPW4' overlaps the line of MSCK2 negative cows at PPW2. The line of MSCK2 positive cows at 'PPW2 and PPW4' overlaps the line of MSCK2 positive cows at PPW2

which was much related to PPHD and milk production loss ${ }^{[3,7-9,11,13]}$. Therefore, the present study used also this cut-point of BBAC. The reason for this discrepancy in the results can be that no BSCK was detected in two Holstein farms, or a seasonal difference might be that a large part of the present study was conducted in the wintertime. Thus, this might indicate that there is no NEB developing in postpartum cows in these farms which resulted in a lower prevalence. Overall, significantly higher BSCK prevalence in Holstein and BBAC and MBAC in PRP cows were detected at PPW2 compared to PPW4 in the present study. This was in compromise with other studies, which reported that the first two weeks postpartum are the most prevalent and critical time points for SCK in Holstein cows ${ }^{[1,13,22-24]}$. Most BSCK positive cows were MUL cows. This was consistent with other studies ${ }^{[13,31-33]}$. However, there are also not consistent reports in Holstein ${ }^{[24,34]}$ and in Jersey ${ }^{[35]}$. The peak prevalence of SCK occurred in the third and fourth week of lactation ${ }^{[4]}$, this result was slightly close to the present study. Similarly, Carrier et al. ${ }^{[24]}$ reported a higher prevalence at PPW1 and 2 than PPW3 and thereafter. It seems to be that BBAC testing should be done earlier but not later than PPW2. Therefore, the test points of the present study set for BAC analysis at PPW2 and PPW4 in the blood and milk was consistent with most of the previously reported studies. The present study reported differently from others an individual BBAC/ BSCK and MBAC/MSCK at PPW2 and PPW4 exactly, while many of studies reported at not an exact time point postpartum $[11,13,19,28,32,36]$. Fat Holstein at calving had significantly higher BBAC at PPW2 and 4 and MBAC at PPW2 in the present study. This was in compromise with the previous reports ${ }^{[33,37]}$. Differently, the present study showed that all thin cows and thin Holstein at calving had higher MBAC at PPW4. The majority of cows lost BCS in PP30 and 60 compared to calving BCS. PRP Holstein with positive BSCK or MSCK lost BCS within 60 days postpartum. Probably, these cows had fat mobilisation due to NEB to compensate energy requirement for the first milk production ${ }^{[19]}$. The prevalence rate of MSCK in the present study was different due to different cut-points of MBAC. The cut-off value of MBAC for the definition of MSCK in the milk varied among the studies ${ }^{[9,14-16,18]}$. $M B A C \geq 200 \mu \mathrm{mol} / \mathrm{L}$ was recommended to define cows having severe and positive ketosis ${ }^{[9]}$ and used also in the previous studies ${ }^{[15,18]}$. Both MSCK1 and MSCK2 prevalence rate was low compared to the literature ${ }^{[14-16]}$ although it was tested at two different postpartum time points. But, MBAC of MUL cows increased significantly at PPW4 compared to PPW2. Consequently, MSCK2 positive Holstein were more likely to develop clinical ketosis although other PPHD such as metritis, mastitis and multiple diseases were observed. SCK was frequently associated with PPHD in Holstein ${ }^{[3,7,8,11,13]}$. The present study showed that BSCK at PPW4 caused a risk for displaced abomasum and lameness without a high significant odd. BSCK positive Holstein at PPW2 and 4 were more likely to develop clinical ketosis. Transformation of SCK into clinical ketosis was frequently reported at a high risk factor and likelihood ${ }^{[2,19,37]}$. BSCK positive Holstein at PPW4 had a nonsignificant incidence of displaced abomasum, because displaced abomasum was overall low in study cows. Displaced abomasum was the most frequently detected metabolic disorder related to SCK in the first weeks after calving with a high-risk factor ${ }^{[1,19,37]}$. Mastitis incidence was frequently high in SCK positive Holstein in the present study. This finding was in line with others $[6,8,13]$, but Suthar et al. ${ }^{[11]}$ did not observe significant risk for mastitis. Differently from others, cows with mastitis have got significantly lower BCS (thin) at calving. Kremer et al. ${ }^{[38]}$ stated that cows with $\mathrm{BBAC}>1.4 \mathrm{mmol} / \mathrm{L}$ were more susceptible to severe mastitis in an experimental E. coli study. MSCK1/2 at PPW4 created a high risk for metritis in Holstein and those cows had significantly high MBAC at PPW4. Similarly, a high metritis incidence was already reported in Turkey and worldwide ${ }^{[2,6,11,13,19]}$. The retained placenta and milk fever as well as cystic ovarian were not observed in Holstein with SCK in the present study. A cutpoint of BBAC for this early PPHD wasn't established previously ${ }^{[11]}$. Others reported high risks for retained 
placenta in association with BSCK ${ }^{[13,37]}$. The cystic ovarian associated with BSCK was reported by previous reports ${ }^{[4,31]}$. Lameness incidence was high and created moderately significant risk in BSCK positive Holstein at PPW4. Similar findings were observed by others in BSCK positive Holstein ${ }^{[11,13]}$. Other study ${ }^{[6]}$ did not report lameness in SCK or clinical ketosis positive Holstein in Turkey. MSCK1/2 and MSCK2 positive cows at PPW4 were significantly more likely to be culled and having metritis and multiple diseases. Similar findings were reported in BSCK and in clinical ketosis in Turkey previously ${ }^{[6]}$. The present study found culling rates in MSCK positive cows and a positive correlation between multiple diseases, metritis and high MBAC additionally. The present study indicated a reduced ADMY in BSCK and MSCK2 positive Holstein which was consistent with the finding of previously reported studies ${ }^{[4,8,19,32,36]}$. MSCK2 positive Holstein had 6.7 kg ADMY loss in 90DIM, it was $4 \mathrm{~kg}$ for cows with positive BSCK at PPW2 or 4. Increasing BBAC above $1.0 \mathrm{mmol} / \mathrm{L}$ during PPW2 was associated with progressively less milk yield ${ }^{[19]}$. A linear negative effect of BBAC beginning at $1.2 \mathrm{mmol} / \mathrm{L}$ at PPW1 was observed on milk production ${ }^{[19]}$. This can result in economic losses throughout the production cycle ${ }^{[7,8,17]}$, e.g., in an average of USD 200-290 per cow ${ }^{[3]}$. Differently from other reports, BSCK at PPW2 resulted in significantly lower ADMY in PRP Holstein. Similar trend was observed in MSCK2 positive PRP Holstein, but the number of animals was not enough to do comparison. Probably, these PRP cows suffered a poor adaptive response to the onset of the first lactation and the resulting NEB ${ }^{[19]}$. A little difference was observed between PRP and MUL cows in hyperketonemia incidence ${ }^{[34]}$. Chandler et al. ${ }^{[35]}$ found more prevalent hyperketonemia in PRP than MUL Jersey cows. A very small difference in ketosis prevalence between PRP and MUL cows was found in Ayrshire and Friesian cows ${ }^{[39]}$. This might lead to the point that PRP Holstein needs more intense care in early lactation to overcome NEB and adapt to the first lactation. However, this was not observed at ADMY between MSCK1 positive and negative Holstein. The lower threshold level of MBAC $(\geq 100 \mu \mathrm{mol} / \mathrm{L})$ for MSCK1 and MSCK1/2 definition at PPW2 or PPW4 did not significantly affect ADMY in Holstein. Previous studies ${ }^{[4,36]}$ reported the association between MSCK1 and reduced milk production in Holstein. A positive moderate correlation between MBAC and BBAC was observed in Holstein, but not in other breeds. Especially, the correlation was high in terms of changes of BBAC and MBAC between PPW2 and PPW4. This correlation between BBAC and MBAC was observed by others ${ }^{[15]}$. In contrast, this correlation was not confirmed between BSCK and MSCK neither at PPW2 and PPW4. The reason might be due to the lower sensitivity of milk BHBA test strips compared to cow-side blood BHBA analysers ${ }^{[24]}$. Semiquantitative determination of MBAC which based on the colour indication for BAC might affect the results. It was stated that concentrations of milk and blood BAC were poorly correlated and the use of milk strips overestimated the concentrations of BAC in the milk ${ }^{[40]}$. The lack of relationship between MBAC and BBAC was observed by Andersson ${ }^{[41]}$ and they suggested that milk BAC could be of low value for the detection of SCK, so that few authors presented a critical cut-off point for MBAC. BHBA can be utilised by the mammary gland for fatty acids synthesis and converted to butyrate ${ }^{[22,42]}$ that is why MBAC is only $10 \%$ to $15 \%$ of BBAC, possibly because of the ketone body's role in fat metabolism in the udder ${ }^{[41]}$. These fluctuations in MBAC in contrast to BBAC may be a reason for the difference of BSCK from MSCK1 and MSCK2 in the present study. But, the prevalence of MSCK in Holstein was often reported higher than the prevalence of BSCK ${ }^{[9,14]}$. Nevertheless, the specificity and sensitivity of the milk test strips used in the present study were confirmed for MBAC in cows ${ }^{[24]}$, but there were still possibilities to observe around $3-5 \%$ false positive and false negative cases, which need to be taken into account by interpreting the milk results. That was the reason why both blood and milk tests were performed for the detection of BSCK and MSCK in the present study. Low BBAC and MBAC in Montbeliard and $\mathrm{HC}$ compared to Holstein and Simmental was an important outcome of this study. SCK was not found in Simmental and HC cows. One Montbeliard exceeded the cut-point of BBAC at PPW2 but not at PPW4. That was irrelevant because no prevalence analysis was conducted due to the small sample number in these breeds and that was also not aimed. In contrast to the present study, a study ${ }^{[43]}$ reported a high incidence of BSCK in Simmental that were in early lactation and late pregnancy. A significantly reduced milk yield was observed in Montbeliard with BSCK in the second month of lactation ${ }^{[44]}$. Simmental cows were mostly culled because of sterility and reproductive diseases, but Montbeliard cows were culled due to poor yield and udder problems ${ }^{[45]}$. The reason for the discrepancy between the results of the studies might be management system differences and parity effect. Thus, the average parity was quite low for Holstein-Crossbreed and Simmental in the present study. Gantner et al. ${ }^{[46]}$ found that the highest prevalence risks of ketosis were observed in 20 DIM of PRP Simmental, parity 2 and 3 cows. The French Simmental family has three strains; Pie rouge de l'Est (or French Simmental), Montbeliard and Abondance ${ }^{[20]}$. Thus, Montbeliard and Simmental cows were classified in the same family of French Simmental ${ }^{[20,21]}$ and they might show a certain extent resistance to SCK ${ }^{[46]}$, especially it can be much obvious under modern management system. Strong resistance of this dual-purpose Simmental Flechvieh breeds to mastitis was reported ${ }^{[20]}$. Although the number of Flechvieh cows looked small compared to Holstein for 
a prevalence analysis in the present study, the resulting evidences about BBAC and MBAC might show the overall trend for SCK development associated to NEB in those breeds. Holstein lost BCS throughout the study period, although other breeds lost BCS at PP30 compared to calving only. Even, Simmental's average BCS at PP60 was similar to calving. This resulted for Holstein in higher BBAC at PPW2 and PPW4 than other breeds with exception of Simmental. No significant change was observed in BBAC between PPW2 and PPW4 in any breeds, however overall MBAC was much higher at PPW2 than PPW4 in PRP Holstein and Montbeliard. Taking all breeds parities into account, it can be speculated that MBAC showed the BCS losses better than BBAC. BCS losses are the result of fat mobilisation due to $\mathrm{NEB}^{[3]}$.

In conclusion, BSCK and MSCK were still a herd problem causing PPHD, culling and ADMY loss in the Holstein farms in Turkey. The prevalence of SCK was much higher at PPW2 than PPW4 and fat cows at calving were more likely to have high BBAC and emaciated and fat cows showed much higher MBAC that was associated with metritis and multiple diseases. BSCK and MSCK2 positive Holstein at PPW2 had an ADMY loss of $6.7 \mathrm{~kg}$. ADMY loss was $7 \mathrm{~kg}$ in PRP Holstein with BSCK at PPW2. The cut-off point of $\mathrm{MBAC} \geq 100 \mu \mathrm{mol} / \mathrm{L}$ did not cause a significant effect on ADMY. However, a higher cut-off point of MBAC $\geq 200 \mu \mathrm{mol} / \mathrm{L}$ (MSCK2) caused a significantly reduced ADMY. BCS losses were better reflected with an increased MBAC at PPW2 in all related breeds. Simmental and related breeds (Flechvieh breeds) might have a certain resistance to SCK, therefore SCK prevalence and its effect on ADMY and PPHD need to be investigated in much larger samples' sizes in all related breeds. PRP Holstein needs to be investigated more intensively in terms of the development of NEB and associated ADMY performance under current modern conditions and high expectations for milk production.

\section{Availability of Data and Materials}

The datasets analyzed during the current study are available from the corresponding author on a reasonable request.

\section{Acknowledgements}

Authors would like to thank all dairy farm owners and veterinarians for their support in this study.

\section{FUNDING AND SUPPORT}

This study was financially supported by Muğla Sitkı Koçman University Research Support and Funding Office (BAP) with the project no: 19/088/04/3/4.

\section{COMPETING INTERESTS}

Authors declare there are no conflicts of interest in the present study.

\section{Author Contributions}

Experimental design and data collection were conceived by KA, AD and ACO. Statistical analysis was conducted by SD and validated by ACO. Original draft was written by $\mathrm{AD}$ and KA. All authors have contributed to the revision and final proof-reading of the manuscript.

\section{REFERENCES}

1. Baumgard LH, Collier RJ, Bauman DE: A 100-year review: Regulation of nutrient partitioning to support lactation. J Dairy Sci, 100, 10353-10366, 2017. DOI: $10.3168 /$ jds.2017-13242

2. Overton TR, McArt AA, Nydam DV: A 100-year review: Metabolic health indicators and management of dairy cattle. J Dairy Sci, 100, 1039810417, 2017. DOI: $10.3168 /$ jds.2017-13054

3. Deniz A, Aksoy K, Metin M: Transition period and subclinical ketosis in dairy cattle: association with milk production, metabolic and reproductive disorders and economic aspects. Med Weter, 76 (9): 495-502, 2020. DOI: $10.21521 / \mathrm{mw} .6427$

4. Dohoo IR, Martin SW: Subclinical ketosis: Prevalence and associations with production and disease. Can J Comp Med, 48, 1-5, 1984.

5. Whitaker DA, Kelly JM, Smith EJ: Subclinical ketosis and serum betahydroxybutyrate levels in dairy cattle. Br Vet J, 139, 462-463. 1983. DOI: 10.1016/s0007-1935(17)30393-7

6. Uyarlar C, Çetingül IS, Gültepe EE, Sial AR, Bayram I: Effects of subclinical and clinical ketosis on the incidence of mastitis, metritis, culling rate and some hematological parameters in dairy cows. Kocatepe Vet J, 11, 186-193, 2018. DOI: $10.30607 / \mathrm{kvj} .419839$

7. McArt JAA, Nydam DV, Overton MW: Hyperketonemia in early lactation dairy cattle: A deterministic estimate of component and total cost per case. J Dairy Sci, 98, 2043-2054, 2015. DOI: 10.3168/jds.2014-8740

8. Raboisson D, Mounié M, Khenifar E, Maigné E: The economic impact of subclinical ketosis at the farm level: Tackling the challenge of overestimation due to multiple interactions. Prev Vet Med, 122, 417-425, 2015. DOI: $10.1016 /$ j.prevetmed.2015.07.010

9. Benedet A, Manuelian CL, Zidi A, Penasa M, De Marchi M: Invited review: $\beta$-hydroxybutyrate concentration in the blood and milk and its associations with cow performance. Animal, 13 (8): 1676-1689, 2019. DOI: 10.1017/S175173111900034X

10. Aksoy K, Deniz A, Metin M: Retrospective study about the transformation of dairy cattle population in Turkey (1991-2019) and possible metabolic and reproductive problems. Black Sea J Health Sci, 4 (2): 77-84, 2021. DOI: $10.19127 /$ bshealthscience. 826702

11. Suthar VS, Canelas-Raposo J, Deniz A, Heuwieser W: Prevalence of subclinical ketosis and relationships with postpartum diseases in European dairy cows. J Dairy Sci, 96, 2925-2938, 2013. DOI: 10.3168/jds.2012-6035

12. Şentürk S, Cihan H, Mecitoğlu Z, Çatık S, Demir Akgül G, Kasap S, Topal O: Prevalence of ketozis in dairy herds in Marmara, Aegean and Mediterranean regions of Turkey. Ankara Univ Vet Fak Derg, 63, 283-288, 2016. 13. Brunner N, Groeger S, Raposo JC, Bruckmaier RM, Gross JJ: Prevalence of subclinical ketosis and production diseases in dairy cows in Central and South America, Africa, Asia, Australia, New Zealand, and Eastern Europe. Transl Anim Sci, 3 (1): 84-92, 2019. DOI: 10.1093/tas/txy102

14. Berge AC, Vertenten G: A field study to determine the prevalence, dairy herd management systems, and fresh cow clinical conditions associated with ketosis in western European dairy herds. J Dairy Sci, 97, 2145-2154, 2013. DOI: $10.3168 /$ jds.2013-7163

15. Denis-Robichaud J, Dubuc J, Lefebvre D, DesCoteaux L: Accuracy of milk ketone bodies from flow-injection analysis for the diagnosis of hyperketonemia in dairy cows. J Dairy Sci, 97, 3364-3370, 2014. DOI: 10.3168/jds.2013-6744

16. Santschi DE, Lacroix R, Durocher J, Duplessis M, Moore RK, Lefebvre DM: Prevalence of elevated milk $\beta$-hydroxybutyrate concentrations in Holstein cows measured by fourier-transform infrared analysis in dairy herd 
improvement milk samples and association with milk yield and components. J Dairy Sci, 99, 9263-9270, 2016. DOI: 10.3168/jds.2016-11128

17. Mostert PF, Bokkers EAM, van Middelaar CE, Hogeveen H, de Boer IJM: Estimating the economic impact of subclinical ketosis in dairy cattle using a dynamic stochastic simulation model. Animal, 12: 145-154, 2018. DOI: $10.1017 /$ S1751731117001306

18. Melendez P, Goff JP, Risco CA, Archbald LF, Littell R, Donovan GA: Incidence of subclinical ketosis in cows supplemented with a monensin controlled-release capsule in Holstein cattle, Florida, USA. Prev Vet Med, 73, 33-42, 2006. DOI: 10.1016/j.prevetmed.2005.08.022

19. Duffield TF, Lissemore KD, McBride BW, Leslie KE: Impact of hyperketonaemia in early lactation dairy cows on health and production. $J$ Dairy Sci, 92, 571-580, 2009. DOI: 10.3168/jds.2008-1507

20. Averdunk G: Dairy Animals: Minor and Dual-Purpose Bos taurus Breeds. Encyclopedia of Dairy Sciences. Page 568-576, Copyright 2002, Elsevier Science Ltd., 2002. DOI: 10.1016/B0-12-227235-8/00109-7

21. Felius M, Beerling ML, Buchanan DS, Theunissen B, Koolmees PA, Lenstra JA: On the history of cattle genetic resources. Diversity, 6, 705-750, 2014. DOI: $10.3390 / \mathrm{d} 6040705$

22. Duffield T: Subclinical ketosis in lactating dairy cattle. Vet Clin North Am Food Anim Pract, 16, 231-253, 2000. DOI: 10.1016/S0749-0720(15)30103-1

23. Khol JL, Freigassner K, Stannitznig A, Tichy A, Wittek T: Evaluation of a handheld device for the measurement of beta-hydroxybutyrate in capillary blood obtained by the puncture of the vulva as well as in venous whole blood in cattle. Polish J Vet Sci, 22, 557-564, 2019. DOI: 10.24425/pjvs.2019.129964

24. Carrier J, Stewart S, Godden S, Fetrow, J, Rapnicki P: Evaluation and use of three cowside tests for detection of subclinical ketosis in early postpartum cows. J Dairy Sci, 87, 3725-3735, 2004. DOI: 10.3168/jds.S00220302(04)73511-0

25. Edmonson AJ, Lean IJ, Weaver LD, Farver T, Webster G: A body condition scoring chart for Holstein dairy cows. J Dairy Sci, 72, 68-78, 1989. DOI: $10.3168 /$ jds.S0022-0302(89)79081-0

26. Heuer C, Schukken YH, Dobbelaar P: Postpartum body condition score and results from the first test day milk as predictors of disease, fertility, yield, and culling in commercial dairy herds. J Dairy Sci, 82 (2): 295-304, 1999. DOI: 10.3168/jds.S0022-0302(99)75236-7

27. Başbuğ O, Akar Y, Ercan N: The investigation of the prevalence of subclinical ketosis in Sivas region dairy cows. Eurasian J Vet Sci, 30 (3): 123 128, 2014.

28. Sahal M, Deniz A, Vural R, Kuplulu S, Polat I, Çolakoglu Ç, Ocal N, Macun Ceyhun H, Pekcan M, Ocak M: Evaluation of the effect of different doses of butaphosphan and cyanocobalamin combination in dairy cattle with subclinical ketozis. Kafkas Univ Vet Fak Derg, 23, 349-356, 2017. DOI: $10.9775 / \mathrm{kvfd} .2016 .16651$

29. Ribeiro ES, Lima FS, Greco LF, Bisinotto RS, Monteiro APA, Favoreto M, Ayres H, Marsola RS, Martinez N, Thatcher WW, Santos JEP: Prevalence of periparturient diseases and effects on fertility of seasonally calving grazing dairy cows supplemented with concentrates. J Dairy Sci, 96, 5682-5697, 2013. DOI: 10.3168/jds.2012-6335

30. Szelenyi Z, Buják D, Nagy K, Boldizsár S, Keresztesi Z, Szekall E, Otto S: Treatment of subclinical ketosis in dairy cattle with a product containing cianocobalamine and butafosfan $\left(\right.$ Catosal $\left.^{\circledR}\right)$. Magy Állatorvosok Lapja, 137, 515-522, 2015.

31. Jordan ER, Fourdraine RH: Characterization of the management practices of the top milk producing herds in the country. J Dairy Sci, 76,

\section{7-3256, 1993. DOI: 10.3168/jds.S0022-0302(93)77661-4}

32. Duffield TF, Kelton DF, Leslie KE, Lissemore KD, Lumsden JH: Use of test day milk fat and milk protein to detect subclinical ketosis in dairy cattle in Ontario. Can Vet J, 38, 713-718, 1997.

33. Vanholder T, Papen J, Bemers R, Vertenten G, Berge ACB: Risk factors for subclinical and clinical ketosis and association with production parameters in dairy cows in the Netherlands. J Dairy Sci, 98, 880-888, 2015. DOI: $10.3168 /$ jds.2014-8362

34. Steen A, Osteras O, Gronstol H: Evaluation of additional acetone and urea analyses, and of the fat-lactose-quotient in cow milk samples in the herd recording system in Norway. J Vet Med, 43, 181-191, 1996. DOI: 10.1111/j.1439-0442.1996.tb00443.x

35. Chandler TL, Pralle RS, Dórea JRR, Poock SE, Oetzel GR, Fourdraine RH, White HM: Predicting hyperketonemia by logistic and linear regression using test-day milk and performance variables in early-lactation Holstein and Jersey cows. J Dairy Sci, 101, 2476-2491, 2018. DOI: 10.3168/jds.2017-13209

36. Gustafsson AH, Andersson L, Emanuelson U: Effect of hyperketonemia, feeding frequency and intake of concentrate and energy on milk-yield in dairy-cows. Anim Prod, 56, 51-60, 1993. DOI: 10.1017/ S0003356100006152 37. Seifi HA, LeBlanc SJ, Leslie KE, Duffield TF: Metabolic predictors of post-partum disease and culling risk in dairy cattle. Vet J, 188, 216-220, 2011. DOI: 10.1016/j.tvjl.2010.04.007

38. Kremer WDJ, Noordhuizen-Stassen EN, Grommers FJ, Schukkken YK, Heringa R, Brand A, Burvenich C: Severity of experimental Escherichia coli mastitis in ketonemic and nonketonemic dairy cows. J Dairy Sci, 76, 3428-3436, 1993. DOI: 10.3168/jds.S0022-0302(93)77681-X

39. Kauppinen K: Prevalence of bovine ketosis in relation to number and stage of lactation. Acta Vet Scand, 24, 349-361, 1983. DOI: 10.1186/ BF03546709

40. Enjalbert F, Nicot MC, Bayourthe C, Moncoulon R: Ketone bodies in milk and blood of dairy cows: Relationship between concentrations and utilization for detection of subclinical ketosis. J Dairy Sci, 84 (3): 583-589, 2001. DOI: 10.3168/jds.S0022-0302(01)74511-0

41. Andersson L: Concentrations of blood and milk ketone bodies, blood isopropanol and plasma glucose in dairy cows in relation to the degree of hyperketonaemia and clinical signs. Zentralbl Veterinaermed, 31, 683-693, 1984. DOI: 10.1111/j.1439-0442.1984.tb01327.x

42. Dodds PF, Guzman MG, Chalberg SC, Anderson GJ, Kumar S: Acetoacetyl-CoA reductase activity of lactating bovine mammary fatty acid synthase. J Biol Chem, 256, 6282-6290, 1981. DOI: 10.1016/S00219258(19)69160-X

43. Djoković R, Kurćubić V, Ilić Z, Cincović M, Petrović M, Fratrić N, Jašović B: Evaluation of metabolic status in Simmental dairy cows during late pregnancy and early lactation. Vet Arhiv, 83 (6): 593-602, 2013.

44. Yameogo N, Ouedraogo GA, Kanyandekwe C, Sawadogo GJ: Relationship between ketosis and dairy cows' blood metabolites in intensive production farms of the periurban area of Dakar. Trop Anim Health Prod, 40, 483-490, 2008. DOI: 10.1007/s11250-007-9124-Z

45. Zółkiewski P, Stanek P, Janus E: Productivity of Simmental and Montbeliarde cows culled in 2005-2016 taking into account the reason for culling. Acta Sci Pol Zootechnica, 17 (1): 15-22, 2018. DOI: 10.21005/ asp.2018.17.1.03

46. Gantner V, Bobić T, Potočnik K, Kučević D, Gregić M: Metabolic disorders in dairy Simmentals - Prevalence risk and effect on subsequent daily milk traits. Mljekarstvo, 68 (2): 77-84, 2018. 